\title{
KIÉ A KÖZJOG?
}

\author{
Horváth M. Tamás ${ }^{1}$
}

Az államtudományok kisajátítására ${ }^{2}$ irányuló törekvés ráirányítja a figyelmet a tudományterületek összefüggéseire. Állam nincs közjog nélkül, amelynek tudományai kiemelten foglalkoznak ezzel a témával. Miként a gazdaság-, a menedzsmentvagyapolitikatudomány is. Az államtéma mindnyájuké, ezért senki másnak ne legyen csak a sajátja.

A közjog a közösségek joga. Hatókörében egy közösségi kormányzási forma és szint az állam. A társadalmi szerveződések müködése, magántársaságok közcélú szerepekben, nonprofit szervek aktivitása, vallási közösségek és egyházak közszolgáltatási tevékenysége, a tradicionális közösségek müködése más további e körbe tartozó megnyilvánulások. Ami a szinteket illeti a helyi és regionális intézmények ,alulról”, a nemzetközi integrációk „,fölülről” egészítik ki a hagyományos államkép formáit.

Az állam a közszektor egyik alakzata. Alkalmazott tudományos megközelítései sokfélék. A hagyományos közjogi szemlélet elsősorban szabályozási felhatalmazást és szabályok rendezett halmazát látta. A modernebb közelítésü jogászok azonban már nemcsak egy-egy részterület rendelkezéseivel foglalkoznak, hanem szakmailag és módszertanilag egyaránt komplex társadalmi regulációs mechanizmusokban gondolkodnak.

A közösség igazgatása másképpen a menedzsmenttudományoknak is a középpontjában áll. A gazdasági megközelítés az állami megoldásokat inkább kormányzási formák egyikének tekinti és azokat a magángazdasággal való összefüggéseiben tárgyalja. Az ilyen fókuszú szemlélet a gazdálkodástudományok körében a legkiterjedtebb.

Az állam továbbá a társadalompolitika ágazati területeinek is fontos, de itt is, legkevésbé sem egyedüli szereplöje. Az ún. közpolitikákat többnyire a politikatudományok szakterületeinek tekintik. Itt azonban nem annyira intézményekkel, pártokkal és effélékkel foglalkoznak, inkább meghatározott jellemző közösségi vagy gazdasági szükségletek célszerüségen alapuló, különböző kielégítési megoldásainak összevetésére és értékelésére összpontosítanak.

Bárhonnan nézzük is, az állam nem tudományos szemlélet, hanem téma. Az alábbi ábra mutatja képletesen az említett összefüggéseket. Régebben a kontinentális Európa egy részében az államtudományokat egy-egyértelmüen a joghoz rendelték. Aztán a közmenedzsment és a közpolitikai irányú megközelítések terjedésével plurálissá váltak a megközelítések és az alkalmazott módszerek, nem is beszélve a képesítést adó szakmákról. Mindnyájuk elönyére válva, tegyük hozzá. A másik kiszorítása mindenesetre föl sem merült másutt legalábbis nem.

\footnotetext{
-A tanulmány a Magyar Tudományos Akadémia és a Debreceni Egyetem Állam- és Jogtudományi Kar közös, MTA-DE Közszolgáltatási Kutatócsoportjának a Területi közszolgáltatások szabályozásai címü projektje keretében készült. A projekt leírására 1.: Horváth M.T.: Szempontok a területi közszolgáltatások regulációs változásainak vizsgálatához. In: HMT (szerk.) Kilengések. Közszolgáltatási változások. Budapest: Dialóg Campus, 2013. 9-25. old.

${ }^{1}$ Horváth M. Tamás, DSc.,tszv. egyetemi tanár, DE ÁJK; kutatócsoport-vezető, MTA-DE Közszolgáltatási Kutatócsoport

2 http://mta.hu/ix osztaly hirei/a-gazdasag-es-jogtudomanyok-osztalyanak-2015-junius-17-i-allasfoglalasa136520/ (letöltés: 2015. 09. 15.)
} 


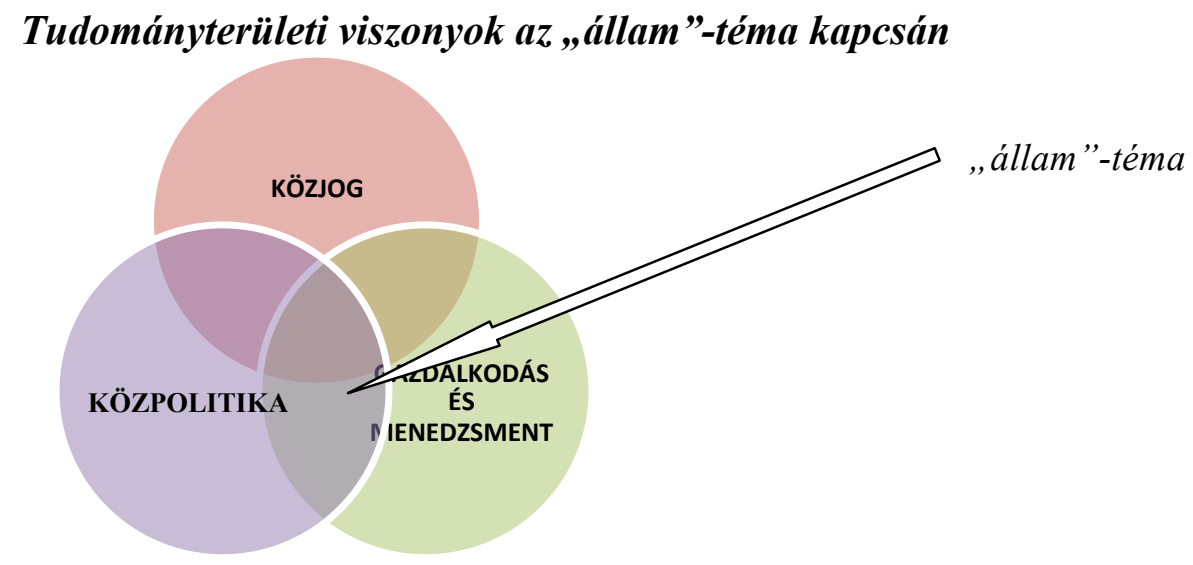

\section{Kapcsolatok a közjogban}

A modern (köz-)jogtudomány a közösség által való elfogadottságból eredezteti a jogot, mely ezért történetileg megelözi az államot. Az amerikai közigazgatási tankönyvek iskolapéldája a zsidó nép, amelyiknek a huszadik század közepéig nem volt állama. Szokása, szervezettsége, erkölcse, vallása, törvényei azonban ősidőktől müködtek.

Minden közjogi diszciplínának mindenkor van sajátlagos eszmei viszonyítási pontja. Még ha ezek különbözőek és időben változóak is, közös a mai fejlett világban a sajátlagos értékelkötelezettség. Ilyen az alkotmányjog tudomány müvelői számára a választóktól kapott felhatalmazás vagy az alapjogok jelentősége, a nemzetközi jognak a nemzetközi közösség léte, a közigazgatási jog tudományos rendszerében a kormányzati szintek demokratikus és önkormányzási karaktere, az európai jog számára az EU szabadságai, valamint a szubszidiaritás elve, a közpénzügyek jogában a piacgazdaságbeli kormányzati szerepek természetének alapul vétele és így tovább.

Nem feltétlenül adott állam hatályos formális jogának jelenségei ezek. Nem is beszélve a maradéktalan megvalósulásukról, ami megfelelö törvényi környezetben is legfeljebb csak az ideák világába való áhított, de soha el nem érhető tökéletesség eszményének volna megfeleltethetö.

A fenti értékeknek egymáshoz ugyanakkor van kapcsolódásuk. A közjog különböző területeinek, tudományos művelésének problémái sok szálon összefonódnak. $\mathrm{Az}$ alkotmányjog vagy az európai jog alapjainak tételezése például a tárgyalt diszciplináris kör mindegyikének kiindulási eleme. De az összefüggések számossága alighanem korlátlannak tekinthetö.

Közülük különösen aktuális a legutóbbi idők változása, amelyik a fenti sajátos értékeken belül és közöttük új típusú konfliktusokat gerjeszt, nyilván eddig nem kellöen fölismert közösségi kihívásokra adott válaszlehetőségek formájában. Kiemelésre érdemesek egyebek mellett a következő kérdések:

- a nemzeti (és esetleg a nemzetek fölötti) alkotmányosság, illetve a globalizáció konfliktusai,

- az integrációs politikák nem várt irányú, mert a korlátokat jobban hangsúlyozó változásai,

- a közfeladatok kiterjedésének mértéke és táguló határai a piacgazdaságban,

- a környezeti fenntarthatóság és a részben benne rejtett gazdaságpolitikai érdekviszonyok konfliktusai és meghatározottságai. 
Mindezeknek és sok mástovábbikonfliktusoskérdésnek a különböző állam- és jogtudományi értelmezései, megközelítései sajátosak, de az adott alapfelvetések komplexitása egyben össze is köti a szakmai érdeklődőket, kutatókat.

A példaként említett új ellentmondások keresztül kasul szabják a közjogi és részben még a magánjogi tárgyak közötti megszokott határokat. Válaszlehetőségeket együtt is érdemes kutatni ezért. Már csak azért is a tudomány nem elvont, hanem praktikus világában, mert aligha jogszabályi kinyilatkoztatások fogják heurisztikusan megoldani a fölmerült problémákat.

\section{A jó hiéna}

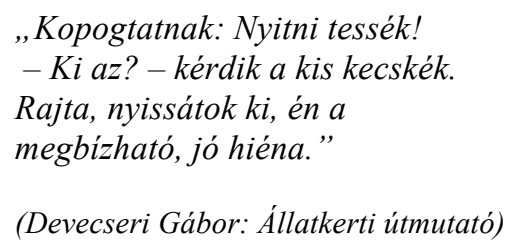

Valaki végzetesen félreérthette a nyugati szakirodalom jó kormányzásról, illetve jó kormányzatról szóló tanulmányait, amikor a terminust a ,jó állam” fogalmaként fordította le. Hiszen nem annyira a viselkedésröl, még kevésbé az önképről van szó.

a) Az állam a közösségeké, miképpen a közszektornak minden más formációja is az övék. A közjognak éppen ezen az alapon témája a közhatalmi megnyilvánulások sora, közte a jogalkotás és a formális közjogi aktusok. Tehát nem fordítva: nem az állam kénye-kedve, tárgya, akarata a jog valósága.

Ilyesmit csak a marxizmus-leninizmus állított. „Jogotok csupán osztályotok törvényre emelt akarata" - írták a Kommunista Kiáltványban majd 170 éve. Viszont mai értelmezésben a jogtudománynak igenis tárgya a törvényeröre emelt akarat minőségének a vizsgálata. Már csak ezért sem jó, ha az állam magának vindikálja a jogot a saját törvényre emelt akarata autentikus értelmezéséhez.

b) Fölmerülhet egy olyan érv is, hogy manapság a kormányzat szerepei kiterjedtebbek, mint a neoliberalizmus modelljében, ezért megalapozott az állam kizárólagosságait jobban biztosítani.

A közszektor-szerepek valóban változás alatt állnak. Az előző alcím alatt fölvetett új problémák, melyek a közjog egészére hatnak, éppen erre utalnak. De az is látszik talán már megfogalmazásuk módjából, hogy az állami megoldás mindnél csak egy a több közül, ráadásul annak milyensége, minősége rendkívül sokféle a világban. A problémakezelés kizárólagossága iránti kétes elhivatottságnak viszont az általunk említett konfliktusok kezeléshez vajmi kevés a köze, mert azzal már egészen más, hatalmi-politikai kérdésekhez jutunk el. Ha csak annyi nem, hogy persze vannak extrém válaszok, amelyeknek hosszabb távú társadalmi költségeivel, bizony, idővel elkerülhetetlenül szembe kell majd nézni.

Mindebből az következik, hogy az állam ma komplexebb és kihívóbb vizsgálati tárgy, mint a korábbi egy-két évtizedben. A közjoggal szembeni kérdések is összetettebbek. A korábbi paradigmákat együtt és egymás szakterületeire tekintettel érdemes szembesíteni, szükség szerint újragondolni.

Ezzel összefüggésben a magánjogi kapcsolatok alakulására is külön figyelmet kell fordítani. Jelentős szerepe van továbbá a fenti ábra közjog-tudományokon kívüli halmazaira és a velük való összefüggésekre való összpontosításnak. 
Végül a kihívásokra való válaszkeresés tartalmai mellett a stílus sem mellékes. Nem mindegy, hogy az államtéma megközelítéseit keressük, vagy a témát annak fontosságára hivatkozással államosítják.

DOI 10.21867/KjK/2015.1.2.

\author{
EZT AKARTUK? \\ LAKOSSÁGI ÉS POLGÁRMESTERI VÉLEMÉNYEK AZ ÚJ HELYI ÖNKORMÁNYZATI RENDSZERRŐL
}

\author{
Péteri Gábor
}

2010. évi politikai váltás egyik meghatározó területe volt a helyi önkormányzati és közszolgáltatási rendszer átalakitása. Itt szükség is volt a változásra, mert egyre inkább megjelentek a városi és falusi élet közötti minöségi eltérések és a részben ezt leképezö területi különbségek. A helyi szolgáltatások színvonala a költségvetési visszafogások következtében és az önkormányzati saját források hiánya miatt romlott. Az elaprózott települési önkormányzati rendszeren belüli koordináció - akár megyei, akár nagyvárosi térségi szinten - az érdekeltség hiánya miatt nem müködött jól. Mindezekkel együtt jártak a helyi igazgatás kapacitás problémái és a decentralizáció miatt jobban láthatóvá váló korrupciós esetek.

Az elmúlt öt év reformjai a helyi önkormányzati rendszer szerteágazó problémáira egysíkú megoldást kínáltak: mindent vissza a központba, korlátozzuk a helyi mozgásteret. A feladatcentralizáció következtében egyharmadával csökkent a helyi költségvetés, hiszen a közoktatás, az egészségügyi ellátás, az igazgatási feladatok jelentős része ma már nem tartozik a helyi önkormányzatok felelösségi körébe. A közüzemi szolgáltatásokban lezajló koncentrációval együtt járt az állami befolyás erősödése, mert az alternatív szolgáltatási formák jelentős versenyhátránnyal indulnak, a szolgáltatási díjakat a minisztériumban határozzák meg. A hitelkonszolidációval látszólag sokat nyertek az önkormányzatok, de valójában az általános, egyedi mérlegelés nélküli hiteltörlesztés nagyon is differenciáló hatású volt, nem beszélve a költségvetési gazdálkodási morálra gyakorolt hatásáról.

A megyei önkormányzat térségi feladat ellátási hatáskörei helyett fejlesztési támogatáselosztó és közvetítő szerepe erősödött meg. A Modern Városok program ${ }^{4}$ egyedi megállapodásai a megyei jogú városokat füzik fel a központi költségvetésre. Miközben a polgármesteri bértábla a kistelepülések vezetőit értékeli le, elindítva egy negatív kiválasztódási folyamatot azokon a településeken, ahol egyébként is csak az önkormányzat az egyetlen közösségi szervezet.

Ennek az új világnak 2013 végére már többségében kialakultak a szabályai. Lassan mind a választott tisztségviselők, mind a szolgáltatásokat igénybe vevő lakosság megismerhette az új helyi önkormányzati rendszer jogi, intézményi, finanszírozási kereteit és érzékelhette a

\footnotetext{
·A bejegyzés az OTKA K 101147 sz., "A városi kormányzás közepes városokban és várostérségekben" címü kutatási projekt [kutatásvezető: Horváth M. Tamás] keretében lefolytatott felmérések, valamint a Magyar Tudományos Akadémia és a Debreceni Egyetem Állam- és Jogtudományi Kar közös, MTA-DE Közszolgáltatási Kutatócsoportjának "Területi közszolgáltatások szabályozásai" címü projektje keretében végzett kutatások alapján készült. [Az utóbbi projekt leírására 1.: Horváth M.T.: Szempontok a területi közszolgáltatások regulációs változásainak vizsgálatához. In: HMT (szerk.): Kilengések. Közszolgáltatási változások. Budapest: Dialóg Campus, 2013. 9-25. old.]

${ }^{3}$ Péteri Gábor, CSc., tanácsadó, LGID Ltd.

${ }^{4} \mathrm{http} / / /$ mandiner.hu/cikk/20150325_indul_a_modern_varosok_program
} 